\title{
Phytoinsecticides to Fight Against Colorado Beetle
}

\author{
S S Basiev¹, A D Bekmurzov², S A Bekuzarova1,3, T A Dulaev¹, L B Sokolova1, \\ Z A Bolieva1, M Ch Datieva1, and L D Khodova1 \\ ${ }^{1}$ Gorsky State Agrarian University, Vladikavkaz, Russia \\ ${ }^{2}$ North Ossetian State University after K. L. Khetagurov, Vladikavkaz, Russia \\ ${ }^{3} \mathrm{Kh}$. Ibragimov Complex Institute of the Russian Academy of Sciences, Grozny, Russia
}

\section{Abstract}

Nowadays researchers are focused on biological farming. In modern environmental conditions the reduction of the chemical load on the environment is a current issue. In the article the following plants are used as pest management, especially, with Colorado potato beetle: jimson weed, white hellebore, Camelina. They contain a lot of alkaloids and essential oils that inhibit weeds and frightening off potato pests. The use of such agricultural practices on large areas reduces the cost of chemical means of pest control and improves product quality while maintaining the environment.

Corresponding Author:

S S Basiev

basiev_s@mail.ru

Received: 25 October 2019

Accepted: 15 November 2019

Published: 25 November 2019

Publishing services provided by

Knowledge E

(c) S S Basiev et al. This article is distributed under the terms of the Creative Commons

Attribution License, which permits unrestricted use and redistribution provided that the original author and source are credited.

Selection and Peer-review under the responsibility of the AgroSMART 2019 Conference Committee.

\section{Keywords: essential oils, alkaloids, ecology, pests, insecticide plants}

\section{Introduction}

Chemical crop protection from herbivores is an important factor in the pollution of agrocoenosis and the environment. Pesticides used to fight against Colorado beetle not only pollute the environment, but also increase the cost of implementing the method [1].

The insecticide Bankol is used to reduce the number of pests [2]. However, the drug is toxic; and it is able to penetrate from leaf surface into internal plant organs. It accumulates of residual quantities of active insecticide substance. At the same time, during the growing season, potato plantations are processed several times when larvae of the first or second age appear. Larvae of the third and fourth ages are especially voracious. It requires additional spraying by sowing with Bankol. It increases pollution.

According to the recommendations of many scientists, a well-managed system of measures is applied, taking into account specific conditions of each specific zone and 
Under production conditions, the problem is carried out with modern insecticides. These drugs are domestic and foreign production (Aktepik, Appulo, Detsis, Inta-VIR, Karate, Sonet, Suli-alfa, Kinmiks, Bankol, Aktar,a Shcherpa, Ekstra, Celman, Mocpilan, Regenet, Tsindbush, Sumitsidin, etc.). When introducing these chemicals, some of them remain in soil and in potato; and soil microflora is depleted [4].

Scientists proposed a number of biological products: Bicol, Bitoxibacuellin, Agrovertin, Colorado, Fitoverm, and others are successfully used on potato crops $[5,6]$.

However, these biological products are used many times in the permanent potato growing of potatoes in an area. It increases the cost of producing such an important food crop [7--9].

In addition, during a number of years soil became exhausted of organic matter in a potato growing in an area.

In order to reduce the cost of fighting against Colorado beetle and preserve soil fertility during the permanent potato growing after harvesting tubers, white mustard was sown with green manure crop. At the end of growing season (late autumn), mustard was mowed down and treated with a mixture of biological preparations Boverin and Actofit in a water concentration of 1 and $0.6 \%$, respectively. Boverin was taken at the rate of 3--4 $\mathrm{kg}$ and Actofit -- 2--2.5 kg per 300--400 liters of water (hectare norm). The moistened mixture was plowed into the soil at a depth of $20--25 \mathrm{~cm}$. The results of the experiments showed that, in the optimal variant, the potato yield reached 31.2 tons per hectare, the incidence decreased from 32 to $6.9 \%$, and the number of beetles from an area of 10 $\mathrm{m}^{2}$ decreased from 26 up to 4 pieces (Table 1).

TABLE 1: Influence of the biological method of fight against Colorado beetle on potato yield.

\begin{tabular}{|c|c|c|c|}
\hline Variants of experiments & $\begin{array}{l}\text { Potato tuber crop, } \\
\text { a ton per hectare }\end{array}$ & $\begin{array}{l}\text { Morbidity of } \\
\text { fusarium, \% }\end{array}$ & $\begin{array}{l}\text { Number of } \\
\text { beetles per } 10 \mathrm{~m}^{2} \text {, } \\
\text { pcs. }\end{array}$ \\
\hline Ploughing pf white mustard & 24,1 & 23,2 & 23,0 \\
\hline Ploughing of mustard and Boverin & 26,8 & 16,4 & 13,0 \\
\hline Ploughing of mustard and Actofit & 26,8 & 13,0 & 9,0 \\
\hline $\begin{array}{l}\text { Ploughing of mustard and the mix of } \\
\text { Boverin and Actofit }\end{array}$ & 31,2 & 6,9 & 4,0 \\
\hline $\mathrm{HCP}_{05}$ & 1,6 & 2,1 & -- \\
\hline
\end{tabular}

Evaluating the biological method, it should be noted that making a mixture of two biological products Boverin and Actofit with plowing the white mustard green manure crop provides good results on the fight against Colorado beetle in industrial crops. 
From the end of July to the end of October white mustard of all green manure crops forms a green mass of up to 30 tons per hectare. In contrast to other green manure crops, mustard contains alkaloids, essential oils, and acids (erucic, oleic, linoleic, lignoceric, myristic, behenic) as well as sinalbin, potash, and myrosin. They reduce pathogenic microorganisms that cause diseases in potato plants.

Mown green mass of mustard treated with an aqueous solution of a mixture of Boverin and Actofit are detrimental to Colorado beetles, which went into hibernation to the soil within $20--25 \mathrm{~cm}$. There the maximum accumulation of pests is noted.

Fungus spores of Boverin (Beauveria bassiana) have antiparasitic action based on the entomopathogenic fungus -- hyphomycetes. Fungus conidia germinate and penetrate into insect body cavities. They dissolve a cuticle with enzymes. Enzymes cause pest death by releasing toxins. Mycelium pervades the entire insect body, forming a layer of conidiophores with conidia on its surface. The owner dies, and conidia are transferred to other individuals.

In the proposed method, wintering bugs die. The concentration of the aqueous solution (1\%) ensures fungus development, and the mixture with Actofit enhances the action of the fungus. Actofit introduced into the mixture at a concentration of $0.6 \%$ of an aqueous solution activates the fungus of Boverin.

Actofit consists of the active ingredient aversectin C -- $0.2 \%$, an alcohol solution of the aversectin C extract -- $59.5 \%$, polyethylene oxide -- 400--0 \%, procsanol CL -- 0.5 $\%$, sulfur-bearing elements. The producer of avermectin complex is a soil actinomycete (streptomy avemitills), which produces a complex close to the structure and the biological properties of substances on natural raw materials in industrial conditions. They also perform a protective function to fight against pests in natural conditions.

Aversektin-bearing drugs are completely harmless to plants, animals and humans.

These results indicate the effectiveness of the method used. However, the implemented method is quite expensive.

Studying a chemical composition of plants, a number of researchers have suggested using them as deterrent agents [10, 11--16]. Such substances may have oilseeds: flax, winter rape, camelina, mustard, and others that contain essential oils [17--20]. In some cases, an aqueous solution of para-Aminobenzoic acid was used. There plants with a high content of essential oils were dissolved [10] 


\section{Methods and Materials}

In order to use an environmentally safe method in the fight against Colorado beetle, pest repellent plants were used: jimson weed (Datura stramonium L.) at a rate of 120--140 $\mathrm{g}$ of dry raw material per 1 liter of water, leaves and berries ща Paris (Paris guadrifolia) in the amount of 70--90 g of dry raw materials per 1 liter of water and in the amount of 150 litres per 1 hectare. After 2--4 days they provided a ploughing in potato crops, when reach the number above the environmental danger threshold [9].

In another experiment, a mixture of jimson weed and Veratum Lobelianum Bernh was injected in an aqueous $0.02 \%$ salicylic acid solution [10]. The first two experiments were carried out in the foothill zone on the experimental base of the North Caucasus Research Institute of Mining and Foothill Agriculture of the Vladikavkaz Scientific Center of the Russian Academy of Sciences in 2016--2018 [10].

In mountain conditions (1,400 above sea level) a culture of winter camelina was used as a deterrent agent. It was sown in autumn with a reduced seeding rate $(1 / 3$ of the norm was 4--5 kg per hectare). Crops were wide-row with $70 \mathrm{~cm}$ spacings. If there is good regrowth in spring, camelina is a lighthouse culture and potatoes are planted in a spacing.

In foothills (600m above sea level) and in mountain conditions, the parameters of the method are experimentally substantiated, taking into account the chemical composition of the selected insecticide plants.

\section{Results}

Datura hyosceolin lowers pest tone, but with the five steroid alkaloids of Veratrum lobelianum it kills Colorado beetle. Dissolved preparations of 2 plants containing a number of substances have a detrimental effect not only on pests: due to the low concentration of salicylic acid, they provide control against potato diseases and heal damaged leaf areas. Salicylic acid solution enhances plant metabolism and photosynthetic activity of cultivated potato crops.

The results of the experiments indicate the advantage of using phytoinsecticides (Table 2).

Table 2 shows that a mixture of 2 types of insecticide plants reduces Colorado beetle from 72.8 to $12.6 \%$, and the number of potato diseases decreases from 42.8 to $8 \%$. The mixture of 2 cultures-phytoinsecticides used in the foothill zone: jimson weed and 
TABLE 2: Effect of phytoinsecticides on pest reduction and diseases of potatoes.

Phytoinsecticides (experience option)
Treatment of crops with water (control)
Treatment of crops with salicylic acid $0.02 \%$
Jimson weed (Datura stramonium L.)
Veratrum lobelianum (Veratrum Lobelianum Ber nh)
A mixture of jimson weed and Veratrum
A mixture of 2 phytoinsecticides and $0.02 \%$ salicylic acid
solution

\begin{tabular}{|c|c|}
$\begin{array}{c}\text { Number of pests } \\
\text { after 4-times } \\
\text { treatment, } \%\end{array}$ & $\begin{array}{c}\text { Potato diseases, } \\
\%\end{array}$ \\
\hline 72.8 & 42.8 \\
\hline 56.4 & 32.1 \\
\hline 45.2 & 23.6 \\
\hline 38.6 & 19.8 \\
\hline 23.0 & 16.1 \\
\hline 12.6 & 8.0 \\
\hline
\end{tabular}

TABLE 3: The number of Colorado beetle in potato crops, depending on the phase of development of winter fungus (\%).

Experience option
Planting potatoes (without camelina) --
64,8
Planting potatoes and Camelia $1 / 2$ of the
seeding rate
Planting potatoes and $1 / 2$ of the seedling
rate
Planting potatoes in spacings $1 / 3$ of the
seeding rate
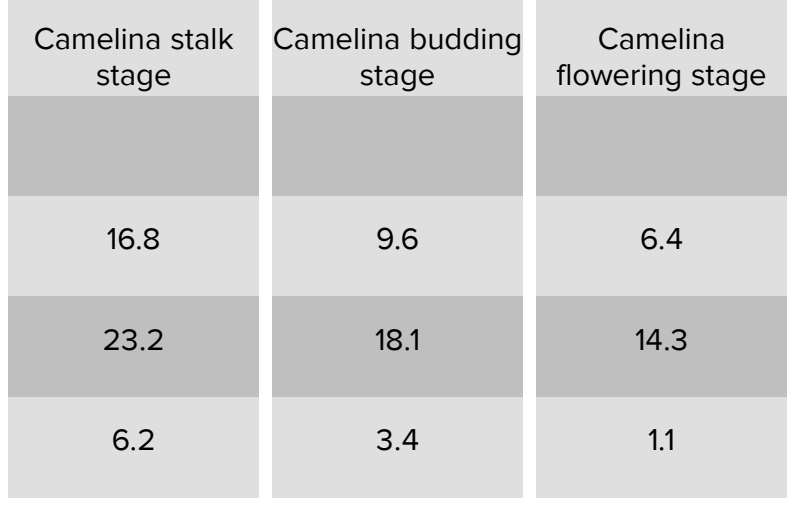

Paris. At 4-times treatment the amount decreased by $24 \%$. It is significantly lower than in the mixture of jimson weed and Veratrum.

Taking into account high plasticity of the Camelina culture and flexibility to growing conditions, one third of the seeds were sown in the range of 4--5 kg in mountainous conditions in the autumn. Camelina silvetris (camelina silvetris subsr piloza N.Sing) contains a complex of essential oils. These are important inhibitors of a number of weeds and repellent pests, in particular, Colorado beetle. The plant contains a number of acids (ferulic and n-coumaric), which are phenolic inhibitors for pests. Camelina silvetris seeds, sown in autumn, create unfavorable conditions for Colorado beetle to spring out of soil for laying eggs on young potato leaves.

Usually, a beetle, which has wintered in soil, comes to the surface of the soil at a temperature of $150^{\circ} \mathrm{C}$. By this period, the highly winter-hardy Camelina silvetris is quite well developed (the height of the plants is more than $20 \mathrm{~cm}$ ).

Plants produces the smell of essential oils, which inhibits and repels Colorado beetle. At the same time, vegetating plants of camelina with $70 \mathrm{~cm}$ spacings are like a 
lighthouse crop to plant potatoes. In addition, in the development of the lighthouse culture, germinations of grain plants are slowed down. It reduces the cultivation of potato spacing and herbicide application.

At the end of May and the beginning of June, the flowering stage of Camelina silvetris begins. It inhibits more beetle flights and weed germinations due to a significant amount of essential oils in phytoinsecticides and their roots.

To this phase of flowering, potato tubers begin to ripen. If it is necessary to obtain new potatoes, they are dug out with the simultaneous cutting of growing plants of camelina, which can be used as a mulching agent; and it prevents the growth of late weeds.

The reduced rate of seeding of camelina (1/3 of the seeding rate) is explained by a high alleleopathic ability. In sparse sowing, plants develop with maximum bushiness and a large number of generative shoots, which provide deterrence of potato pests and inhibit weed germination in the row spacing.

The results of the experiments indicate that the number of Colorado beetle in crops of potatoes with an inter row arrangement of winter crab is reduced (Table 3 ).

Table 2 confirms that Camelina silvetris sown in spacings of potatoes provides a significant reduction in individuals of pests. The agricultural practice does not require additional costs for expensive insecticides. The method in large areas will reduce costs and provide an opportunity to get environmentally-quality products. At the same time, Camelina silvetris scares other pests of potatoes. The remaining plants of Camelina, followed by incorporation into the soil, enrich it with organic matter.

\section{Conclusion}

The use of insecticide plants reduces the number of pests from 72.8 to $12.6 \%$ due to alkaloids and essential oils they contain. Dissolved dry substances of plants of jimson weed and Veratrum lobelianum in an aqueous solution provide high-quality products of potatoes, reducing toxic load on soil microflora.

Crops of Camelina silvetris in spacings of potatoes are inhibitors of diseases and pests, reducing their number in the flowering stage of phytoinsecticide of Camelina silvetri from 64.8 to $1.1 \%$. 


\section{References}

[1] Bekuzarova, S.A., Gavdinova, R.V., Zapoev, Yu.N., Khadikova, T.B. (2005). Fight Method against Colorado potato beetle"Patent no. 2245033, published February 27, Bull. no. 3, MPK AO1M 1/20, AO1№ 25/00

[2] Melnikov, N.N., Novozhilov, K.V., Belan, S.R. (1995). Pesticides and plant growth regulators. Moscow: Khimiia, $333 \mathrm{p}$.

[3] Kalinina, K.V. (2017). Biological support for the protection of potatoes from the Colorado potato beetle (decemlineata Say) in the North-West Region of Russia. $\mathrm{PhD}$ dissertation thesis. Velikiye Luki, $38 \mathrm{p}$.

[4] Konarev, A.V., Fasulati, S.R. (1996). Proteinases of Colorado potato beetle and their plant protein inhibitors. XX Intern. Congr. Entomol. Proc. Firenze, 182 p. Italy.

[5] Mowry, T. (2002). Effects of sub-lethal imidacloprid levels on potato leafroll virus transmission by Myzus persicae. Entomologia Experimentalis et Applicata, vol. 103, pp. 249--255.

[6] Biological plant protection with phytoncides. Retrieved from: //htt:kuetok.r/uredliteli/biologicheskaya-zashhita-rastemij-ot. ure...

[7] Fermander, M., Zentner, R., De Paum Gehl, R.D., Stevenson, F. (2007). Impacts of Crop Production factors on Common Root Rot of Barley in Eastern Saskatchewan. Crop Science, no. 4, pp. 47.

[8] "The list of pesticides and agrochemicals permitted for use on the territory of the Russian Federation in 2015. (2015)..Appendix to the journal Protection and quarantine com plants, no. 4, 720 p.

[9] The method of fight against Colorado beetle. (2005). Patent no. 2225033., published 27.01.2005, IPC A01M1/20.

[10] Method of fight against Colorado potato beetle. (2016). Patent no. 2586901, published 10.06.2016, Bul. no. 16 of the IPC A01M1/ 00.

[11] Grafiu, E. (1999). Economic impact of insecticide resistance in the Colorado potato beetle on the Michigan potato industry. Entovmol, vol. 9, no. 5, pp. 1144--1151.

[12] Kang, J.H., Baldwin, I.T. (2006). Isolation-and characterization of the threonine deaminase promoter in Nicotiana attenuate. Plant Sci., no. 171, pp. 435--440.

[13] Foster, S. (2003). Variation in response to neonicotinoid insecticides in peach-potato aphids. Myzus Science, vol. 59, no. 2, pp. 166--173.

[14] Bishop, B., Grafiu, E., Zhao, J.-Zh. (2000). Inheritance and Synergism of Resistance to Imidacloprid in the Colorado Potato Beetle (Coleoptera: Chrysomelidae). Journal of Economic Entomology, vol. 93, no. 5, pp. 1508--1514. 
[15] Maxwell, J.C. (1892). A Treatise on Electricity and Magnetism, 3rd ed., vol. 2. Oxford: Clarendon, pp. 68--73.

[16] Jacobs, I.S., Bean, C.P. (1963). Fine particles, thin films and exchange anisotropy. Magnetism, vol. III, New York: Academic. pp. 271--350.

[17] Elissa, K. Title of paper if known. unpublished.

[18] R. Nicole, "Title of paper with only first word capitalized", J. Name Stand. Abbrev., in press.

[19] Yorozu, Y., Hirano, M., Oka, K., Tagawa, Y. (1982). Electron spectroscopy studies on magneto-optical media and plastic substrate interface, IEEE Digests 9th Annual Conf. Magnetics Japan, vol. 2, pp. 740--741.

[20] Young, M. (1989). The Technical Writer's Handbook. Mill Valley, CA: University Science. 